\title{
USE OF ADVANCED TEACHING METHODS IN THE TRADITIONAL SYSTEM OF MEDICAL EDUCATION-AN OVERVIEW
}

\author{
Kamath Mahusudana \\ Former Associate Professor, Division of Ayurveda, Centre for Integrative Medicine and Research, \\ Manipal Academy of Higher Education, Manipal, 576104 \\ Honorable Legal Advisor Kamath \& Kamath Associates \\ Mandya - 571401, Karnataka, India
}

Article DOI: $\underline{\text { https://doi.org/10.36713/epra4648 }}$

\begin{abstract}
Globalization and information technology has made an impact on education. Experts don't want to compromise in the quality of the teachers. The market influences the teachers. The drastic shift in Education is observed in the present era, now a day everything is commercialized and student treated as a client. Advances in medical education are greatly influencing contemporary medical teaching. It is right time us to focus on these issues and deliver the quality education to traditional system learns.
\end{abstract}

KEYWORDS: Teaching, Traditional, Medical education

\section{INTRODUCTION}

It is the right time to introduce the policy, which gives importance to the need for renovating the quality of the traditional medical educational system by using skilled manpower with advanced teaching aids. As far as traditional medical education is considered, only quality teaching will not help the purpose of future students, Quality teaching must include the exercises like placement, self -development, building confidence, Industry institution interaction, keeping in pace with the latest technologies, Interdisciplinary and inter professional activities etc. play a vital role. More work has to be done in this arena. This review on the traditional medical education system is based on research to discover descriptive and analytical knowledge, ${ }^{1}$ The knowledge measurement is a process of the practice of creating, acquiring the knowledge 2 Revolution in information technology brings a lot of changes in the traditional medical education system of teaching. Usually, the traditional medical education system of teaching is always teacher-centred, and students found very difficult to collect the resources, But the same scenario is different in contemporary science. It is based on the proper use of teaching aids with information technology. So this is the right time to integrate traditional medical education system of teaching with proper use of advance teaching methodologies along with information technology.

According to Schneideheinze both student and teacher-centered have their own positive and negative impact on the delivery of the curriculum. It is the right time to implement advances in medical education like task-based learning, case-based learning, and problembased learning and flipped classroom for the betterment of traditional medical education system.

\section{FLIPPED CLASSROOM}

Flipped classroom as an educational method that involves two parts one is interactive activities in the class, and another one is computer-based instruction. It is based on technology, for instance, many research articles not open assesses in nature, but you may get 


\section{EPRA International Journal of Research and Development (IJRD)

thousands of various forms traditional system of medicine articles is available for open access in Publon, Scopus, DHARA, and CINHAL like a search engine.

The traditional system of education must adopt advanced strategies, to meet the higher outcomes and recognition from accreditation institutions like NAAC, AICT, ABET (Accreditation Board for Engineering and Technology)

\section{PROBLEM-BASED LEARNING}

Problem-based learning methods are more effective 3 in teaching clinical subjects, clinical methods and improves self-directed problem-solving skills ${ }^{4}$.

\section{COOPERATIVE LEARNING}

It is one more type education method ${ }^{5}$ describe cooperative learning as including, where Students working to attain the goal.

According to many scholars 6, 7, this method motivates Positive interaction, and increase interpersonal skills which are more important in strategic planning like diagnosis, planning treatment as well as disease management ${ }^{8}$. But in Problem based learning is Student-Centered where teacher role is just as a facilitator, this is a brainstorming study method but have its constraints, as it is useful in Small Student Groups, requires motivation and careful monitoring 9

\section{ACTIVE LEARNING}

It is to the maximum extent matches the traditional way of teaching ${ }^{10}$. Here the advances in the delivery of medical education mainly depend upon creativity. Here the teacher is facilitator, motivator, and using an enormous variety of sources. All these sessions are brainstorming and improve the quality outcome.

We all know about higher education, and various methods we are using in pedagogy .but how it differs from medical education the medical education is based on "learn to apply to learn". This gives an opportunity to the students' knowledge, skill as well as attitude.

In other words, there is a clear conflict between the traditional system of pedagogy and advanced pedagogy.

\section{E-LEARNING}

Revolution in information technology brings a lot of changes in the traditional system of teaching. Usually, the traditional system of teaching is always teacher-centered, and students found very difficult to collect the resources. So this is the right time to integrate the traditional system of teaching with technology.

You can implement e-learning more effectively in medical education. Where we have to adopt the student-centred learning process.

It is very difficult to come to a conclusion in this stage as both traditional and advances in medical education.

The main feature of e-learning is an autonomous one, advance delivery of study material is possible. It helps the student to study the topic in advance before attending classes and discuss with their teachers.

These advances in the delivery of medical education mainly depend upon creativity. Here the teacher is facilitator, motivator, and using an enormous variety of sources. All these sessions are brainstorming and improve the quality outcome.

We all know about higher education, and various methods we are using in pedagogy .but how it differs from Higher education is based on "learn to apply to learn". This gives an opportunity to the student's knowledge, skill as well as attitude.

\section{DISCUSSION}

This is the right time to adopt traditional and contemporary medical science must focus on delivering quality medical education system. The University Grant Commission (UGC) permitting and encouraging teachers from the industry. It is a great facilitator in the medical education globalization has encouraged in their specialist to join inter-country organizations. The concurrent permission from them for these specialists to be teachers in Medical colleges is noteworthy. Though the regularity agencies don't count such inputs in terms of headcount. The appreciation of quality control agencies has helped private medical college joins hands with industry in a broad sense. However other quality control agencies appreciate the inputs from the industry to facilitate wider exporter of products from medical colleges. A suggestion made by a few experts to adopt American education modal of Adjunct professors has attracted the attention of a few experts. Corporate participating education enterprise is likely to push no retiring age. As in some western countries. The argument of few experts is that of National scenario, a politician not having retirement age, same also experts in the industry. What do you think about researching by medicos?

Why doctors there are many causes which hinder doctors by conducting the research. There are many reasons. The main reason is that $\mathrm{PhD}$ scholars to do more biomedical research compare to doctors. One more reason is the cost of cross-training in research as 


\section{SJIF Impact Factor: 7.001| ISI I.F.Value:1.241| Journal DOI: 10.36713/epra2016 ISSN: 2455-7838(Online) EPRA International Journal of Research and Development (IJRD) Volume: 5 | Issue: 6 | June 2020 - Peer Reviewed Journal}

well as clinical practice. The main issues related to impeding are scientific, ethical as well as a regulatory one. The scientific issues are related In other words, there is a clear conflict between the traditional system of pedagogy and advanced pedagogy.

Teaching is considered a noble profession, which is a unique and privileged sector universally.In Advanced or new paradigm in pedagogy, academician and students excited about coming to work together and work hard. There are no enormous words, here no fearless and no pedagogy, It is just like a conversation with a friend. And when we teach we have to use heart not mind. As French physicist rightly said the "heart has its reasons, which reasons knows nothing of". It is our responsibility to develop a team with advanced teaching skills but it is enough? no isn't enough. Each number needs the glue that is the hallmark of a new paradigm of pedagogy.

The biggest issue in the US system is that medical schools cannot afford for their physicians to be doing research, which reimburses their salary at the rate of grants, instead of seeing patients, which brings in much more money. Another issue is that NIH protects the time of physicians who get career awards and while this keeps helps them focus on research it keeps them from seeing patients and keeping clinical skills up.

\section{CONCLUSION}

The dynamic market place in education appropriate dynamic intervention and emulations in the educational experience. Medical education must adopt Current innovations which are competency-based and give Future directions for medical education research. Teaching is considered a noble profession, which is a unique and privileged sector universally. In Advanced or new paradigm in pedagogy, academician and students excited about coming to work together and work hard. There are no enormous words, here no fairness and no pedagogy, it is just like a conversation with a friend. And when we teach we have to use heart not mind. As French physicist rightly said the "heart has its reasons, which reasons knows nothing of". It is our responsibility to develop a team with advanced teaching skills but it is enough? No isn't enough. Each number needs the glue that is the hallmark of the new paradigm of pedagogy.

\section{REFERENCES}

1. Kothari CR. Research methodology: Methods and techniques. New Age International; 2004.

2. Scarborough H, Swan J, Preston J. Knowledge management-the next fad to forget people. InProceedings of European Conference on Information Systems, Copenhagen 1999: 668-6781

3. Felder RM ., Brent R., Designing and teaching courses to satisfy the ABET engineering criteria. Journal of Engineering Education,2003 92(1):7-25

4. Hmelo-Silver CE. Problem-based learning: What and how do students learn? Educational Psychology Review, 2004: 16(3):235-266

5. Foot H,.Howe. The psychoeducational basis of peer-assisted learning. In K.J. Topping and S.W. Ehly, editors, Peer-Assisted Learning, pages 27-43. Lawrence Erlbaum Associates, 1998.

6. Johnson DW., Circles of Learning: Cooperation in the classroom. Association for supervision and curriculum development, Alexandria, VA, 1984.,

7. Doolittle PE. Understanding cooperative learning through Vygotsky. In Lily National Conference on Excellence in College Teaching, Colombia, SC, June 2-4 1995.

8. Barrows. Problem-based learning in medicine and beyond: A brief overview. New Directions for Teaching and Learning, 1996(68):3-12

9. Gijbels D., Dochy F., Van den Bossche P., Segers M. Effects of problem-based learning: A metaanalysis from the angle of assessment. Review of educational research, 2005, 75(1):27-61.

10. Prince M. Does active learning work? A review of the research. Journal of Engineering EducationWashington 2004, 93:223-232. 